\title{
A Study Case on the Impact of Prolonged Exposure to Cell Phone Radiation, among Iraqi Students, on RBC- AChE Activity
}

Zahraa S. Al-Garawi ${ }^{2 *}$, Falah S. Al-Fartusie ${ }^{1}$, Haidar B. Al-Mandlawi ${ }^{2}$ and Nmark K. Al-Zaidi ${ }^{2}$

${ }^{1}$ Department of Biochemistry, School of Science, University of Sussex, UK

${ }^{2}$ Department of Chemistry, Al-Mustansyriah University, Iraq

\begin{abstract}
The effects of moderate and extreme exposure to radiofrequency electromagnetic radiation (RFR), emitted from mobile phones, on the activity of RBC-acetylcholinesterase (AChE) were investigated. AChE activity was measured using UV-Vis spectroscopy by Ellman modified method. The results showed that prolonged exposure (3-5 hrs.) to RFR, among young male undergraduate students (18-25 year ages), increased enzyme activity; while the main inactivation took place in moderate exposure (1-2 hrs.). In conclusion, according to the changes observed in the AChE activity, it is proposed that an increase in the duration of RFR exposure causes an increase in cholinergic activity.
\end{abstract}

Keywords: Mobile phone radiation; RBC- Acetycholinestrase activity; Ellman method of ache assay

Abbreviation: RFR: Radiofrequency Electromagnetic Radiation; SAR: Specific Absorption Rate; CNS: Central Nervous System; AChE: Acetylcholinesterase; ACh: Acetylcholine; RBC: Red Blood Cell; EMF: Electromagnetic Field.

\section{Introduction}

The increase in the usage of telecommunication devices, available to a large number of individuals $\left(>10^{9}\right.$ worldwide and the number is increasing exponentially), and the time individuals spend connected to these devices has aroused concerns of possible interactions on human body by Radiofrequency electromagnetic radiation (RFR) [1].This form of energy, (10 KHz-300 GHz in the electromagnetic spectrum), emitted from mobile telephones and cellular masts antennas, easily penetrates into organic tissues and gets absorbed and converted into heat; the familiar use of this energy is in cooking by the microwave ovens [2]. It has been identified that $80 \%$ of the radiation emitted by a cell phone is absorbed by the head of adult human beings.

There are many factors that affect the distribution of energy absorbed, in an irradiated organism which are non-uniform, and also lead to the formation of so called 'hot spots' of concentrated energy in the tissue in certain areas of the head. Chou and co-workers have reported that two brain regions, less than a millimeter apart, can have more than two-folds differences in specific absorption rates (SARs) when different areas of rat brain were exposed to RFR for long time [3]. The situation is more complicated if the animal is moving in a RF field. Depending on the amount of movement of the animal and duration of the exposure, the energy absorbed in its body could become either more complex or unpredictable or more uniform i.e. it looks just like a microwave oven with a rotating carousel that provides more uniform heating of the food than one without [4-6].

Several studies have indicated a possible effect of Electromagnetic fields (EMF) emitted from mobile phone on brain activity; including sleep [7], attention [8], learning and memory $[9,10]$ and cognitive performance [11]. Moreover, it has been proposed that a brain harmed by RFR of mobile phone might derive to modify electrophysiological activity in human brain [12] and to alter neurotransmission [13]. These effects depend on amperage, frequency and exposure duration [14].

An another study shows that radiation from a mobile phone disrupts the structure and biochemical characteristics of the most important enzyme in the central nervous system (CNS) acetylcholinesterase (AChE ), especially among young people [15]; the enzyme is also known as acetyl hydrolase (E.C. 3.1.1.7). It is a serine protease found mainly in neuromuscular junctions and cholinergic brain synapses, it conducts tissue like: nerve and muscle, central and peripheral tissues, motor and sensory fibers $[16,17]$ where its activity serves to terminate the signal transmission during neurotransmission process. This is achieved through hydrolyzing the neurotransmitter acetylcholine $(\mathrm{ACh})$ as is released from the nerve into the synaptic cleft relying the signal from the nerve $[18,19]$.

The enzyme has also been detected, in a large amount, in human Red blood cells (RBCs) [20,21]. Therefore, suppressed and/or increased AChE function in the peripheral and central nervous system (CNS) can be monitored by RBC-AChE as a biomarker [22] .

On the basis of the foregoing contradictory conclusions and in order to further identify whether prolonged usage of the mobile phone is a healthy and safe on the nervous system or not, we are currently conducting experiments to study the effects of long-time exposure to mobile phone, among student in the Chemistry Department, on the activity of RBC-AChE where it's the first attempt in our city to clarifying that situation.

\section{Materials and Methods}

All chemicals were purchased from Sigma Chemical Company.

\section{Sample collection}

Blood collected from healthy male volunteer students from the Chemistry Department/ College of Science/Al-Mustansyriah University, under an approved Human Subject Protocol. This casecontrol study was carried out on 90 young students between October

*Corresponding author: Zahraa S. Al-Garawi, Department of Chemistry, AlMustansyriah University, Iraq, Tel: 07901332812, E-mail: zahraa_algarawi@yahoo.com

Received August 23, 2012; Accepted September 20, 2012; Published September 24, 2012

Citation: Al-Garawi ZS, Al-Fartusie FS, Al-Mandlawi HB, Al-Zaidi NK (2012) A Study Case on the Impact of Prolonged Exposure to Cell Phone Radiation among Iraqi Students, on RBC- AChE Activity. Biochem Anal Biochem 1:116 doi:10.4172/2161-1009.1000116

Copyright: ( 2012 Al-Garawi ZS, et al. This is an open-access article distributed under the terms of the Creative Commons Attribution License, which permits unrestricted use, distribution, and reproduction in any medium, provided the original author and source are credited. 
2011 and May 2012. The study group included 25 students, who used the mobile phones about (1-2 hrs. / day) continuously for 5 days per week. The other group of 30 students used cell phone for (5-8 hrs. / day) continuously nearly 5 days/week. The rest 35 students represented the normal sporadic use (10-20 min. daily). Their ages ranged from 18-25 years and they had no history of Epilepsy or any neurological related diseases. All subjects were used mobile phone directly without head phone, no one live near the cell phone implants and the study was restricted by the usage of cell phone only not affected by other outside antenna.

Blood of all students groups was collected in EDTA tube and kept on ice. Within 4 hours of collection, the sample was centrifuged in a centrifuge at $3000 \mathrm{rpm}$ for $15 \mathrm{~min}$, then RBCs were separated and stored at $4^{\circ} \mathrm{C}[23]$.

\section{Acetylcholinesterase Assay}

AChE activity was measured for RBCs using a modified colorimetric method developed by Ellman and co-workers [24] based on the following reactions;

Acetylethiocholine iodide $+\mathrm{H}_{2} \mathrm{O} \longrightarrow$ Ache Thiocholine + Acetate

Thiocholine + Dithiobisnitrobenzoic acid (DNTB) $\longrightarrow$ 5-Thio-2nitrobenzoate

(Yellow)

The principle of the method depends on the measurement of the rate of thiocholine production when acetylthiocholine iodide is hydrolyzed by AChE. This is accomplished by the continuous reaction of the thiol with DTNB (Ellman reagent) to produce the yellow product (equations 1 and 2 above). The enzyme activities were measured by following the increase in absorbance at $412 \mathrm{~nm}$ for $4 \mathrm{~min}$. intervals resulting from the formation of this color product. The general enzymatic reaction can be summarized in equations 3 and 4 :

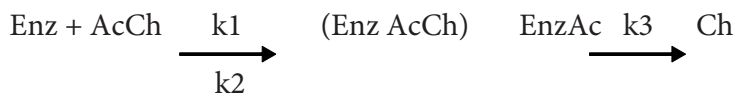

$\mathrm{EnzAc}+\mathrm{H} 2 \mathrm{O}$

$$
\mathrm{k} 4 \mathrm{Enz}+\mathrm{AcOH}
$$

Where: Enz is the enzyme, $\mathrm{AcCh}$ is the substrate $(\mathrm{ACh})$, and $\mathrm{Ch}$ and $\mathrm{AcOH}$ are the products (choline and acetic acid, respectively) [25].

Solutions:

Buffer: Phosphate, 0.1 M, pH 8.0.

Substrate: Acetylthiocholine iodide, ${ }^{\star} 0.075 \mathrm{M}(21.67 \mathrm{mg} / \mathrm{ml})$.

Reagent: Dithiobisnitrobenzoic acid (DTNB) $0.01 \mathrm{M}$ of the 5 : 5-dithiobis-2-nitrobenzoic acid $39.6 \mathrm{mg}$ were dissolved in $10 \mathrm{ml} \mathrm{pH}$ 7.0 phosphate buffer $(\mathrm{O}-1 \mathrm{M})$ and $15 \mathrm{mg}$ of sodium bicarbonate were added. The reagent was made up in buffer of $\mathrm{pH} 7$.

\section{Method for RBC}

(1) A suspension of the blood cells in phosphate buffer ( $\mathrm{pH}$ 8.0, $0.1 \mathrm{M})$ was prepared.

The most practical dilution was $1: 600$ ( $10 \mu 1$ blood into $6 \mathrm{ml}$ buffer).

(2) Exactly $3.0 \mathrm{ml}$ of the suspension were pipette into a cuvette.

(3) If only red cell cholinesterase was desired, $10 \mu \mathrm{l}$ of $0.1 \%$ per cent quinidine sulfate was added to inhibit plasma esterase.

(4) Of the DTNB reagent, $25 \mu \mathrm{l}$ of DTNB and finly $20 \mu$ of substrate were added to this cuvette. Changes in absorbance at (412 ท́m) were recorded for $4 \mathrm{~min}$.

\section{Calculations}

Moles of substrate hydrolyzed $/ \mathrm{min} .=(4.41)\left(\mathrm{lo}^{-14}\right) \mathrm{A} \Delta$

Where: $4.41\left(10^{-14}\right)=$ factor for dilution, extinction coefficient.

$\Delta \mathrm{A}=$ change in absorbance $/ \mathrm{min}$.

\section{Statistical analysis}

The data are expressed as means $\pm \mathrm{SD}$. $(n)$, where $\mathrm{n}$ refers to the number of students. Statistical comparisons between the means of mild and prolonged exposure to EMR of mobile phone and those of normal usage carried out by T-test using SPSS version16. Significance was determined at $\mathrm{p}<0.05$. Person correlation coefficients Tow-tailed was used to correlate between time exposure and the enzyme activity, correlation is significant at the 0.05 level.

\section{Results}

The enzyme activity of AChE clearly exhibits an important increase after mild to high usage of mobile phone continuously compared to that of normal speaking $(5.02 \pm 1.27 v s .4 .23 \pm 1.27 \mathrm{~mol} / \mathrm{min} ., \mathrm{p}<$ 0.02). According to Table 1, it appears noticeably that the AChE rate is highly dependent on the usage time of the mobile phone. The data show that the average rate of the AChE increases when there is an increased exposure to the radiation of cell phones $(\mathbf{r}=\mathbf{0 . 2 5}, \mathbf{p}<\mathbf{0 . 0 5})$ implying an enhancement in the hydrolysis of ACh iodide.

In order to consider the effect of exposure to mobile connection on changes of AChE activity, the present analysis, described in Table 2, shows the clear significant increase in the enzyme activity after $\mathbf{1 . 8}$ $\mathrm{hr}$ and $\mathbf{4 . 0 2} \mathrm{hr}$ as a mean time for individuals with normal exposure $(4.89 \pm 1.04$ and $5.11 \pm 1.27 v s .4 .23 \pm 1.27$ respectively, $\mathrm{p}<0.001)$, nevertheless this enhancement increases linearly with time $(\mathbf{r}=\mathbf{0 . 4 6}$, $\mathbf{p}<0.05$ ).

\section{Discussion}

The most important issue, as regards mobile phone usage, is the duration of exposure, while the mobile phone is in the near field and localized at the head region; however, this exposure has been proved as a non-thermal in nature [26-28].

Three experiments were embedded into this study; first: with normal speaking emission (10-20 min daily), second: with moderate speaking emission (1-2 hrs. /day continuously), and the third group was with highly speaking emission (3-5 hrs. / day continuously). The exposure in these cases, while connected, simulates the situation of listening and talking by users through mobile phone. Results are listed in Tables 2, they evidently show a high rate of AChE as the user being closed to the cell phone for a long time.

\begin{tabular}{|c|c|c|c|c|c|c|c|}
\hline Enzyme test & \multicolumn{3}{|c|}{ Normal exposure students } & \multicolumn{4}{|c|}{ Mild to high Exposure students } \\
\hline & Mean $\pm s(n)$ & $p$ & $\%$ & $\begin{array}{c}\text { Mean } \pm \\
s(n)\end{array}$ & $p$ & $\%$ & $r$ \\
\hline $\begin{array}{c}\text { AChE activity } \\
* 10^{-15} \text { Mol/min }\end{array}$ & $\begin{array}{c}4.23 \pm \\
1.27(35)\end{array}$ & 0 & 45.7 & $\begin{array}{c}5.02 \pm \\
1.27(60)\end{array}$ & $0.001^{* *}$ & 54.2 & \\
\hline Time of exposure & $\begin{array}{c}14.2 \text { min } \pm \\
1.22(35)\end{array}$ & & & & $\begin{array}{c}3.1 \mathrm{hr} \\
\pm 1.3(60)\end{array}$ & & $0.25^{*}$ \\
\hline
\end{tabular}

$p^{*}$ : significant, $p^{* *}$ : very significant

Table 1 : Results of RBC-AChE activity tests in different groups of students. 


\begin{tabular}{|c|c|c|c|c|c|c|c|c|c|}
\hline \multirow{2}{*}{$\begin{array}{l}\text { Effect } \\
\text { tests }\end{array}$} & \multicolumn{2}{|c|}{ Normal } & \multicolumn{3}{|c|}{$\begin{array}{l}\text { Mild exposure } \\
\text { students }\end{array}$} & \multicolumn{4}{|c|}{ High exposure students } \\
\hline & $\begin{array}{c}\text { Mean } \pm \\
s(n)\end{array}$ & $\%$ & $\begin{array}{c}\text { Mean } \pm \\
s(n)\end{array}$ & $p$ & $\%$ & $\begin{array}{c}\text { Mean } \pm \\
s(n)\end{array}$ & $p$ & $\%$ & $r$ \\
\hline Age & $\begin{array}{l}21.45 \pm \\
1.68(35)\end{array}$ & 33.03 & $\begin{array}{c}22.32 \\
\pm 1.36 \\
(25)\end{array}$ & $0.01^{*}$ & 34.7 & $\begin{array}{l}21.17 \pm \\
2.5(35)\end{array}$ & N.S & 32.5 & \\
\hline $\begin{array}{l}\text { Time of } \\
\text { exposure }\end{array}$ & $\begin{array}{c}14.2 \\
\min \pm \\
1.22(35)\end{array}$ & 3.80 & $\begin{array}{c}1.80 \\
\mathrm{hr} \pm \\
0.4(25)\end{array}$ & -- & 29.7 & $\begin{array}{c}4.02 \mathrm{hr} \\
\pm 0.95 \\
(35)\end{array}$ & -- & 66.4 & 0.46 \\
\hline $\begin{array}{l}\text { AChE } \\
\text { activity } \\
{ }^{*} 10^{-15} \\
\mathrm{Mol} / \mathrm{min}\end{array}$ & $\begin{array}{c}4.23 \pm \\
1.27(35)\end{array}$ & 29.7 & $\begin{array}{c}4.89 \\
\pm 1.04 \\
(25)\end{array}$ & $0.003^{* *}$ & 34.3 & $\begin{array}{l}5.11 \pm \\
1.27 \\
(35)\end{array}$ & $0.0001^{\star \star *}$ & 35.9 & \\
\hline
\end{tabular}

$p^{*}$ : significant, $p^{* *}$ : very significant, $p^{* * *}$ : highly significant, N.S: no significance

Table 2: Frequency of RBC-AChE activity in relation to a history of students' duration exposure.

The results in this study strongly suggest that the RFR action causes a rise in the enzyme rate, when there is an RFR exposure for long time. Similar results have been reported previously, the RFR affects and enhances AChE activity in nervous system-derived cells in culture was also observed earlier [29]. In the case of RFR-induced changes in cholinergic activity in the brain, another previous study demonstrates that there is an increase in cholinergic activity in the hippocampus in rat after the session of sham exposure; consequently there is a deterioration in functions of cells [30].

In the framework of the importance of AChE modifications induced by the RFR, comparatively to the physiological one, it has been shown that the modification occurs in the same order observed with patients who attained Alzheimer disease [31], where there is a decline in ACh. Therefore, the principal medicines are suppressants of AChE in order to compensate for this decrease of the neurotransmitter. This result is, in one way or another, correlates with the suggestion of a recent study [32]. The afore-mentioned study showed that the EMF radiation directly affects neurons by reducing the neuronal reactivity, increasing the neural membrane conductivity, and prolonging their refractory period [32].

It is of significance, here, to mention that an indication from literature suggests that the prolonged exposure, to radiation emitted, affects the brain of younger humans faster than older humans by speeding up the brain response time; and this is, in fact, the slowest process of modifying the normal brain stability which is lead to creating senility in a younger humans [15].

Compared to the studies of Barteri and co-workers on solution of electric eel, and Vukova and co-workers on frog skeletal muscles, the present work did not confirm such an effect of RFR [15,27]. They have found, in contrary to our results, that decrease in enzyme activity accompanies a change in its biochemical characteristics. More recently, the same decrease in AChE activity has been recorded with changes observed in the secondary and tertiary structure of the enzyme. These changes in enzyme structure would limit the binding of substrate to the enzyme active site; leading to inactivation of the enzyme [25]. Also, a significant decrease in acetylcholinesterase activity was found in rats exposed to RFR for longer term ( 3 hrs. / day), but rats exposed for short-term periods showed no significant effect on AChE activity [33].

In fact, the observed contrasts, between different studies, are expected since no similar conditions have ever been applied between different studies. Besides, this could be attributed to the different sources of enzymes used. Moreover, the sea of information liberated from extensive research on acetylcholinesterase in vertebrates and invertebrates indicates that the effect on vertebrate, especially in mammalian CNS, is more complicated than on invertebrate depending on the fact that the invertebrate AChE is not a typical vertebrate enzyme, but exhibits properties (kinetics and sequence analysis) intermediate to that of vertebrate AChE. This is particularly based on comparing the structure of ChE in vertebrate and invertebrate [34]. Such changes in AChE activity are also not identical between animals and humans; the recent toxicology studies failed to detect any significant effect of phone radiation on animal health, yet this does not prove that humans are safe and that the current safety standards protect all users.

\section{Acknowledgement}

The present work was supported by the research plan of Chemistry dep., ALMustasyriah University.

\section{References}

1. Hyland GJ (2000) Physics and biology of mobile telephony. Lancet 356: 18331836.

2. Lai H (1998) Neurological effects of radiofrequency electromagnetic radiation In "Workshop on Possible Biological and Health Effects of RF Electromagnetic Fields", Mobile Phone and Health Symposium, University of Vienna, Vienna Austria.

3. Chou CK, Guy AW, McDougall JA, Lai H (1985) Specific absorption rate in rats exposed to $2,450-\mathrm{MHz}$ microwaves under seven exposure conditions. Bioelectromagnetics 6: 73-88

4. Dimbylow PJ (1993) FDTD calculations of the SAR for a dipole closely coupled to the head at $900 \mathrm{MHz}$ and $1.9 \mathrm{GHz}$. Phys Med Biol 38: 361 .

5. Dimbylow PJ, Mann SM (1994) SAR calculations in an anatomically realistic model of the head for mobile communication transceivers at $900 \mathrm{MHz}$ and 1.8 GHz. Phys Med Biol 39: 1537-1543.

6. Martens L, De Moerloose J, De Zutter D, De Poorter J, De Wagter C (1995) Calculation of the electromagnetic fields induced in the head of an operator of a cordless telephone. Radio Science 30: 283-290.

7. Hamblin DL, Wood AW (2002) Effects of mobile phone emissions on human brain activity and sleep variables. Int J Radiat Biol 78: 659-669.

8. Edelstyn N, Oldershaw A (2002) The acute effects of exposure to the electromagnetic field emitted by mobile phones on human attention. Neuroreport 13: 119-121.

9. Koivisto $M$, Krause $C M$, Revonsuo A, Laine M, Hämäläinen H (2000) The effects of electromagnetic field emitted by GSM phones on working memory. Neuroreport 11: 1641-1643.

10. Koivisto M, Revonsuo A, Krause C, Haarala C, Sillanmäki L, et al. (2000) Effects of $902 \mathrm{MHz}$ electromagnetic field emitted by cellular telephones on response times in humans. Neuroreport 11: 413-415.

11. Nittby H, Grafström G, Tian DP, Malmgren L, Brun A, et al. (2008) Cognitive impairment in rats after long-term exposure to GSM-900 mobile phone radiation. Bioelectromagnetics 29: 219-232.

12. Huber R, Treyer V, Borbély AA, Schuderer J, Gottselig JM, et al. (2002) Electromagnetic fields, such as those from mobile phones, alter regional cerebral blood flow and sleep and waking EEG. J Sleep Res 11: 289-295.

13. Ahmed N, Asaad A, Aboul-Ezz H, Radwan N (2006) Effect of exposure to electromagnetic radiation from the mobile phone on acetylcholinesterase activity in the hippocampus and striatum of young and adult male rats. Med $J$ Cairo Univ 77: 405-407.

14. Seyyedi SS, Dadras MS, Tavirani MR, Mozdarani H, Toossi P, et al. (2007) Proteomic analysis in human fibroblasts by continuous exposure to extremely low-frequency electromagnetic fields. Pakistan Journal of Biological Sciences 10: $4108-4112$

15. Barteri M, Pala A, Rotella S (2005) Structural and kinetic effects of mobile phone microwaves on acetylcholinesterase activity. Biophysical Chemistry 113 245-253.

16. Massoulie J, Pezzementi L, bon S, Krejci E, Vallette FM (1993) Molecular and cellular biology of cholinesterases. Progress in Neurobiology 41: 31-91. 
Citation: Al-Garawi ZS, Al-Fartusie FS, Al-Mandlawi HB, Al-Zaidi NK (2012) A Study Case on the Impact of Prolonged Exposure to Cell Phone Radiation, among Iraqi Students, on RBC- AChE Activity. Biochem Anal Biochem 1:116. doi:10.4172/2161-1009.1000116

17. Chacko LW, Cerf JA (1960) Histochemical localization of cholinesterase in the amphibian spinal cord and alterations following ventral root section. J Anat 94 : 74-81.

18. Koelle GB (1954) The histochemical localization of cholinesterases in the central nervous system of the rat. J Comp Neurol 100: 211-235.

19. Katzung BG (2001) Introduction to autonomic pharmacology In Basic and clinical pharmacology 8ed 75-91, McGraw Hill Companies, New York.

20. Ballard CG, Greig NH, Guillozet-Bongaarts AL, Enz A, Darvesh S (2005) Cholinesterases: Roles in the brain during health and disease. Curr Alzheimer Res 2: 307-318.

21. Dvir H, Harel M, Bon S, Liu WQ, Vidal M, et al. (2004) The synaptic acetylcholinesterase tetramer assembles around a polyproline II helix. EMBO J 23: 4394-4405.

22. Nigg HN, Knaak JB (2000) Blood cholinesterases as human biomarkers of organophosphorus pesticide exposure. Rev Environ Contam Toxicol 163: 29112.

23. Wilson BW (2005) Improving Blood Monitoring of Enzymes as Biomarkers of Risk from Anticholinergic Pesticides and Chemical Warfare Agents, U.S. Army Medical Research and Material Command Fort Detrick, Maryland 21702-5012, University of California Davis, California

24. Ellman GL, Courtney KD, Andres Jr V, Featherstone RM (1961) A new and rapid colorimetric determination of acetylcholinesterase activity. Biochemical Pharmacology 7: 88-95.

25. Ezzatollah F, Raheleh F (2012) Effect of electromagnetic field on acetylcholinesterase activity: In vitro study. African Journal of Biochemistry Research 6: 8-13.
26. Behari J (2010) Biological responses of mobile phone frequency exposure, Indian J Exp Biol 48: 959-981.

27. Vukova T, Atanassov A, Ivanov R, Radicheva N (2005) Intensity-dependent effects of microwave electromagnetic fields on acetylcholinesterase activity and protein conformation in frog skeletal muscles. Med Sci Monit 11: 50-56.

28. Diem E, Schwarz C, Adlkofer F, Jahn O, Rüdiger H (2005) Non-thermal DNA breakage by mobile-phone radiation $(1800 \mathrm{MHz})$ in human fibroblasts and in transformed GFSH-R17 rat granulosa cells in vitro. Mutation Research / Genetic Toxicology and Environmental Mutagenesis 583: 178-183.

29. Dutta S K, Das K, Ghosh B, Blackman CF (1992) Dose dependence of acetylcholinesterase activity in neuroblastoma cells exposed to modulated radio-frequency electromagnetic radiation. Bioelectromagnetics 13: 317-322.

30. Lai H, Horita A, Chou CK, Guy AW (1987) Effects of low-level microwave irradiation on hippocampal and frontal cortical choline uptake are classically conditionable. Pharmacol Biochem Behav 27: 635-639.

31. Silman I, Hermona S, Anglister L, Michaelson D, Fischer A (2004) Cholinergic Mechanisms: Function and Dysfunction, Taylor \& Francis, UK.

32. Kaprana AE, Karatzanis AD, Prokopakis EP, Panagiotaki IE, Vardiambasis IO et al. (2008) Studying the effects of mobile phone use on the auditory system and the central nervous system: A review of the literature and future directions. Eur Arch Otorhinolaryngol 265: 1011-1019.

33. Kunjilwar KK, Behari J (1993) Effect of amplitude-modulated radio frequency radiation on cholinergic system of developing rats. Brain Research 601: 321 324

34. Gouri A (2004) Acetylcholinesterase [AChE] activity and isozyme pattern in normal and lithium-treated developing chick brain. Neuroscience. 